EMPOWER: Jurnal Pengembangan Masyarakat Islam

Vol. 5, No. 2, Desember 2020, hlm. 40-56

e-ISSN : 2580-0973, p-ISSN : 2580-085X

Tersedia online di : http://syekhnurjati.ac.id/jurnal/index.php/empower

Email : empowerjurnal@gmail.com

\title{
Kebijakan Pembangunan Desa Inklusif: Analisis Monitoring dan Evaluasi di Kelurahan Sidorejo, Kulonprogo D.I Yogyakarta
}

\author{
Mutrofin* \\ (Program Studi Pengembangan Masyarakat Islam, UIN Sunan Kalijaga Yogyakarta) \\ Email: rofinhegel@gmail.com
}

\section{Ageng Widodo**}

(Program Studi Pengembangan Masyarakat Islam, IAIN Purwokerto)

Email: Widodoageng009@Gmail.com

\section{Article History}

Submitted: 25.09.2020; Revised: 19.10.2020; Accepted: 14.12.2020;

\begin{abstract}
The implementation of village government regulations $B A B \quad 7$ concerning community empowerment and village community assistance which is manifested in the formation of inclusive villages is a key instrument that is the focus of the government in realizing a just and prosperous society. This paper aims to research and review the continuity of monitoring and evaluation of the Inclusion Village in Sidorejo Village, Ledah District, Kulon Progo Regency, D.I Yogyakarta. This study used a qualitative method by sampling data from informants from the community and government stakeholders. The results of the study indicate that the development of an inclusive village will provide opportunities for people who have the opportunity to get greater welfare. Reviewing monitoring and evaluation in the Inclusive Village in Sidorejo Village, Kulonprogo, there are several stages, at the monitoring stage in the form of information and participation data, while the evaluation stage has improvements in equality of access to public services, supportive regulations, budget planning that mainstreams inclusion, social problems in society.
\end{abstract}


Keyword: inclusive village development, monitoring, evaluation

\begin{abstract}
Abstrak
Implementasi peraturan pemerintah desa $\mathrm{BAB} \quad 7$ tentang pemberdayaan masyarakat dan pendampingan masyarakat desa yang diwujudkan dalam pembentukan desa inklusi merupakan instrumen kunci yang dijadikan fokus pemerintah dalam mewujudkan masyarakat adil dan makmur. Pada tulisan ini bertujuan untuk meneliti dan meninjau keberlangsungan monitoring dan evaluasi Desa Inklusi di Kelurahan Sidorejo Kecamatan Ledah Kabupaten Kulon Progo D.I Yogyakarta. Penelitian ini menggunakan metode kualitatif dengan sampling data dari informan yang berasal dari masyarakat dan pemangku pemerintah. Hasil dari penelitian menunjukan bahwa pembangunan desa inklusi akan memberikan kesempatan bagi masyarakat yang memiliki peluang mendapatkan kesejahteraan lebih besar. Meninjau monitoring dan evaluasi di desa Inklusi di Kelurahan Sidorejo, Kulonprogo terdapat beberapa tahap, pada tahap monitoring berupa data informasi dan partisipasi sementara tahap evaluasi terdapat perbaikan pada kesetaraan akses layanan umum, relulasi yang mendukung, perencanaan anggaran yang mengarusutamakan inklusi, problem sosial dalam masyarakat.
\end{abstract}

Kata Kunci: pembangunan desa inklusi, monitoring, evaluasi

\title{
PENDAHULUAN
}

Konteks kesejahteraan secara tradisional mengarah kepada tanggungjawab pemerintah yang harus diberikan kepada masyarakat. Dalam hal ini masyarakat hanyalah objek yang bersifat pasif dan harus dipenuhi kebutuhannya oleh pemerintah. Namun, kebijakan dalam konteks yang lebih luas mengarah kepada tanggungjawab seluruh elemen negara untuk bergerak dalam proses kesejahteraan ${ }^{1}$. Pemenuhan kebutuhan masyarakat dapat direalisasikan melalui pendistribusian kebijakan yang mencangkup seluruh wilayah di Indonesia tidak terkecuali wilayah

\footnotetext{
${ }^{1}$ Andrew Heywood, Political Theory (Hampspire: Palgrave Macmillan, 2004). 
pedalaman yang belum tersentuh modernitas sehingga tidak adanya setralisasi kesejahteraan dan pembangunan².

Cita-cita bangsa Indonesia dalam mensejahterakan masyarakat telah diformulasikan dalam Alinea kedua pembukaan Undang-Undang dasar 19453. Potret tujuan nasional Bangsa Indonesia dalam pembukaan Undangundang Dasar 1945 yaitu "membentuk suatu pemerintahan Negara Republik Indonesia yang melindungi segenap bangsa Indonesia dan seluruh tumpah darah Indonesia, memajukan kesejahteraan umum, mencerdaskan kehidupan bangsa, dan ikut berperan aktif dalam melaksanakan ketertiban dunia yang berlandaskan kemerdekaan, perdamaian abadi dan keadilan sosial".

Berdasarkan empat poin tersebut, maka pemerintah memiliki fokus dalam merealisasikan kebijakan yang adil dan menyeluruh untuk masyarakat Indonesia. Dari empat point tersebut, dua teratas berisi mengenai perlindungan terhadap seluruh tumpah darah Indonesia dan memajukan kesejahteraan umum. Sehingga dua poin tersebut menjadi fokus utama dalam pelaksaan pemerintah. Pemerintah tidak bisa berjalan sendiri dalam merealisisasikan kebijakan tersebut. Pelaksanaan pemerintah haruslah melibatkan masyarakat secara partisipatif sehingga tidak kehilangan makna dan proses perencanaan serta penganggaran dalam ranah kebijakan publik.

Secara umum professional, proporsional dan akuntabel harus bisa diterapkan dalam proses perencanaan dan penganggaran sebagai landasan penerjemahan kebijakan. Perencanaan dan penganggaran partisipatif yang pro poor, gender responsive dan inklusifitas bagi masyarakat merupakan wahana untuk mempraktikan prinsip-prinsip tata kelola demokratis dan good governance. Dimana kesetaraan, keadilan, non-violence, toleransi, inklusivitas, transparansi, akuntabilitas, dan responsifitas menjadi prinsipprinsip utama. Adanya perencanaan dan penganggaran pelaksanaan

2 Chrisna, "Action for Sustainability: Preparing an African Plan for Sustainable Building and Construction'," Building Research E Information, 2015, 435-44.

3 Steffanie, "The Convergence of Alternative Food Networks within 'Rural Development' Initiatives: The Case of the New Rural Reconstruction Movement in China," Local Environment, 2016, 1082-99. 
pemerintahan yang partisipatif menjadi prioritas instrumen kunci yang menjadi titik masuk bagi perwujudan masyarakat yang terlindungi, adil dan makmur.

Keharusan melibatkan warga dalam perencanaan dan penganggaran untuk memastikan dan mengidentifikasikan apa yang menjadi prioritas pembangunan, kebijakan, program dan kegiatan yang membutuhkan alokasi anggaran atau sumber daya merupakan bentuk partisipatif. Warga dalam hal ini merupakan seluruh elemen masyarakat yang tidak membatasi, artinya tidak adanya pengecualian baik dari perspektive gender, masyarakat miskin, masyakat marginal dan penyandang disabilitas.

Pembentukan Desa Inklusi merupakan salah satu bentuk dalam pelaksanaan perencanaan dan penganggaran pemerintahan sebagai upaya pencapaian masyarakat yang partisipatif. Otonomi Desa yang diatur berdasarkan Undang-Undang Republik Indonesia Nomor 6 Tahun 2014 Tentang Desa telah memberikan keterbukaan bagi terlaksanaannya Desa Inklusi. Desa inklusi sendiri merupakan pemikiran yang lahir dari semangat untuk membangun gerakan desa mandiri dengan pelayanan prima. Desa inklusi yaitu desa yang terbuka, dialogis, merangkul dan toleran. Seperti tertera dalam Bab I Pasal 3 tentang Pengaturan Desa, yang mana Desa haruslah berasaskan pada; rekognisi, subsidiaritas, keberagaman, kebersamaan, kegotong-royongan, kekeluargaan, musyawarah, demokrasi, kemandirian, partisipasi, kesetaraan, pemberdayaan dan keberlanjutan.

Berdasarkan regulasi di atas, desa tidak memiliki keterbatasan dalam penyelenggaraan pemerintahan yang baik bagi segenap masyarakatnya. Desa Inklusi sebagai sistem dan jaringan yang mendukung pemenuhan hak masyarakat arginal, difabel dan orang dengan kemampuan berbeda. Yang termasuk difabel yaitu; penyandang disabilitas, lansia, anakanak, ibu hamil, orang dengan kebutuhan khusus dan lainnya. Hal tersebut merupakan sesuatu yang harus dipenuhi untuk membangun desa inklusi.

Maka dari hal tersebut keberlangsungan dari desa inklusi ini tentunya membutuhkan pemantauan dan pengawasan dalam bentuk monitoring dan evaluasi. Monitoring dan evaluasi dilaksanakan dengan tujuan: mengetahui bagaimana masukan (input) sumber-sumber dalam 
rencana digunakan, bagaimana kegiatan-kegiatan dalam implementasi dilaksanakan, apakah rentang waktu implementasi terpenuhi secara tepat atau tidak, apakah setiap aspek dalam perencanaan dan implementasi berjalan sesuai dengan yang diharapkan, mengidentifikasi tingkat pencapaian tujuan, mengukur dampak langsung yang terjadi pada kelompok sasaran, serta mengetahui dan menganalisis konsekuensikonsekuensi lain yang mungkin terjadi diluar rencana (externalities).

Fenomena ini menjadi daya tarik penulis untuk melakukan penelitian, satu sisi ingin melihat bagaimana implementasi desa inklusif selain itu juga melihat bagaiamana potret pelaksanaan monitoring dan evaluasi desa inklusif. Kajian ini memiliki rumusan masalah pertama, bagaimana monitoring desa inklusif di kelurahan Sidorejo, Kulongprogo D.I. Yogyakarta. Kedua, bagaimana evaluasi desa Inklusif Kelurahan Sidorejo, Kulonprogo D.I. Yogyakarta.

Beberapa penelitian lain yang membahas tema ini adalah: pertama karya Kadek Dwita Apriyani dengan judul "Respon Publik terhadap Model Penganggaran Partisipatif dalam Pembangunan Desa: Studi Tiga Provinsi di Indonesia" ${ }^{\prime \prime}$. Karya ini membahas tentang model penganggaran partisipatif dalam pembangunan desa yang merujuk pada program dana desa. Dalam teknisnya terdapat perbedaan anatra data desa dengan jumlah, rekrutmen pendaming desa serta sarat pencairan dana desa. Sehingga program ini dirasa kurang efektif dan dampaknya tidak dirasakan langsung oleh masyarakat. Program dirasa tidak mendapat respon yang baik dari masyarakat sehingga berdampak pada partisipasi masyarakat secara keseluruhan. Secara umum tujuan penelitian ini mendeskripsikan tentang respon publik terhadap dana desa di wilayah Indonesia Barat yang diwakili oleh provinsi Banten, wilayah Indonesia Tengah yang diwakili oleh Gorontalo dan Indonesia Timur oleh Papua. Temuan dalam penelitian ini

4 Edi Suharto, Membangun Masyarakat Memberdayakan Rakyat: Kajian Strategis Pembangunan Kesejahteraan Social Dan Pekerjaan Social (Bandung: PT. Refika Aditama, 2009).

5 Kadek Dwita Apriyani, "Respon Publik Terhadap Model Penganggaran Partisipatif Dalam Pembangunan Desa: Studi Tiga Provinsi Di Indonesia," Jurnal Penelitian Politik 13, no. 2 (2016): 137-48. 
terdapat $50 \%$ yang menilai bahwa penggunanaan dana desa di wilayahnya tepat sasaran. Penilaian masyarakat di tiga daerah tersebut berkaiatan dengan budaya masyakata setempat. Partisipasi masyarakat bisa dilihat dari intensitas mereka dalam mengikuti rembug desa, semakin tinggi partisipasi masyarakat maka kecenderungan respon untuk mengetahui dana desa akan meningkatkan nalar kritis serta aksi pemberdayaan yang mengacu pada desa inklusi dalam masyarakat.

Kedua, karya Eka Suaib dkk, dengan judul "Desentralisasi dan Oligarkhi Predator di Wakatobi: Peran Oligarkhi dan Elit Penentu dalam Pembangunan Perdesaan"6. Karya ini membahas tentang kehadiran ologarkhi di Wakatobi yang menumbuhkan usaha baru, membuka lapangan pekerjaan dan meningkatkan jumlah wisatawan. Namun hal ini juga berdampak pada ketimpangan pendapatan dan konflik lahan. Lahirnya UU no 6 tahun 2014 tentang desa membuka peluang dalam mengelola keuangan desa. Salah satu program yang diberikan pemerintah denagn pemberian dana desa 9:1 hal ini untuk meningkatakn kesejahteraan masyarakat. Namun program ini dirasakan kurang maksimal oleh Sebagian masyarakat karena belum melibatkan peran aktif dalam masyarakat dalam pengelolaan dana desa.

Ketiga, karya Yusuf Maulana dengan judul "Membangun Kemandirian Desa Dalam Bingkai Otonomi Daerah"7. Karya ini membahas tentang berbagai persoalan desa yang kompleks mulai dari persoalan desentralisasi desa yang belum jelas, posisi desa, masalah struktur dan fungsi kelembagaan pemerintah desa yang belum sesuai dengan kebutuhan desa dan masyarakat. Dalam membangun kemandirian, pemerintah desa menerapkan UU no 6 Tahun 2014 dengan pendekatan inklusi sosial. Harapan dengan model ini maka partisipasi masyarakat meningkat serta program-program dalam masyarakat akan berjalan dengan baik sehingga tingkat pemberdayan meningkat.

\footnotetext{
${ }^{6}$ Eka Suaib and Et Al, "Desentralisasi Dan Oligarkhi Predator Di Wakatobi: Peran Oligarkhi Dan Elit Penentu Dalam Pembangunan Perdesaan," Jurnal Penelitian Politik 13, no. 2 (2016): 193-211.

7 Yusuf Maulana, "Membangun Kemandirian Desa Dalam Bingkai Otonomi Daerah," Jurnal Penelitian Politik 13, no. 2 (2016): 261-68. 
Berdasarkan beberapa penelitain di atas, penulis berasumsi artikel ini layak dikaji kembali secara mendalam, karena memiliki perbedaan dan fokus kajian. Masalah yang dipecahkan. Penelitian ini menggunakan metode kualitatif dengan mengahasilkan data deskriptif berupa pernyataan tertulis dan lisan dari informan yang diamati ${ }^{8}$. Dalam penelitian ini, penulis menguraikan data-data terkait monitoring dan evaluasi penerapan desa inklusif di kelurahan Sidorejo, Kulonprogo, D.I. Yogyakarta. Sampel penelitian ini dilakukan dengan metode purposive sampling yang secara disengaja dipilih berdasarkan sifat-sifat, kriteria, karakteristik yang sesuai pada kebutuhan pada penelitian ini. Metode pengumpulan data yang dilakukan adalah dengan wawancara, observasi dan studi dokumentasi.

\section{HASIL DAN PEMBAHASAN}

\section{Inklusi Sosial, Pembangunan Desa, dan Potret Kelurahan Sidorejo Kulonprogo}

Inklusi sosial merupakan proses di mana individu maupun kelompok dalam masyarakat diberi kesempatan untuk terlibat dalam berbagai sistem sosial, ekonomi, politik maupun pendidikan. Catatan Bank Dunia memaparkan bahwa konsep inklusi sosial tidak boleh hanya dilihat sebagai proses itu sendiri tetapi juga sebagai hasil. Ini karena begitu kebijakan inklusif dirumuskan dan diterapkan dalam masyarakat tertentu, keragaman dihargai, memungkinkan semua orang untuk hidup bahagia dengan cara terlibat dalam kebijakan. Selain itu, inklusi sosial juga menciptakan peluang dan kemampuan bagi individu, semua orang dan memberi mereka rasa hormat untuk hidup dalam identitas mereka9 .

Inklusi sosial menciptakan perubahan positif dalam lingkungan sosial tertentu sehingga praktik dan keadaan yang menciptakan pengucilan sosial dapat dihilangkan. Di berbagai negara termasuk Indonesia, berbagai langkah diambil fokus mengarah pada inklusi sosial. Salah satu langkah awal adalah berbagai program pengentasan kemiskinan, kebodohan dan

8 De los Rios, "The Initiative Leader as a Model for Rural Development: Implementation to Some Territories of Mexico," Agrociencia, 2011, 609-24.

${ }_{9}$ Michael Woolcock, Social Inclusion: Its Significance for Development Theory, Research and Policy (Paris: Harvard University, 2013). 
secara politis meningkatkan partisipasi individu maupun kelompok sehingga masyarakat survive termasuk mendapatkan peluang di sekitar mereka. Ini juga bertujuan untuk memungkinkan orang berpartisipasi secara aktif dalam pengaturan sosial dan menyuarakan pendapat mereka. Kebanyakan ahli percaya bahwa jika langkah-langkah ini dilakukan, masyarakat akan menikmati akses ke semua layanan ${ }^{10}$.

Ide inklusi sosial telah muncul pada paruh kedua abad kedua puluh, yaitu berbagai kebijakan yang dirumuskan oleh pemerintah fokus pada berbagai level termasuk individu, masyarakat, negara maupun hubungan internasional. Kemajuan dalam domain hak asasi manusia selama enam dekade terakhir mencapai puncaknya pada pengakuan hak asasi manusia atas layanan air dan sanitasi dalam dua deklarasi oleh Majelis Umum Perserikatan Bangsa-Bangsa dan Perserikatan Bangsa-Bangsa Dewan Hak, keduanya pada tahun 2010. Pasca kolonialisme, banyak negara berkembang termasuk Indonesia berjuang untuk mendapatkan kembali kontrol dan kedaulatan atas sumber daya alam mereka. Sehingga Inklusi sosial melawan eksklusivitas, melawan hal yang mengarah pada konsentrasi kekayaan dan atau konsentrasi kenaikan gaji di sektor-sektor tertentu, meningkatkan tingkat partisipasi publik, dan mengurangi kesenjangan dalam pengetahuan, kapasitas dan pendapatan, dengan fokus pada komunitas tertentu yang terpinggirkan dan dikucilkan dari akses ke fasilitas dan peluang sosial ${ }^{11}$.

Inklusivitas menjadi fokus utama dari pendekatan alternatif untuk melawan dominasi paradigma neoliberal dan untuk menciptakan ruang dalam konsep pembangunan bagi yang termiskin dan lingkungan. Masih belum jelas apakah pendekatan inklusif dapat memberikan penyeimbang yang memadai terhadap paradigma neoliberal, tetapi paling tidak dapat membantu secara bertahap memberikan koreksi pada sistem melalui penyediaan tujuan misalnya tujuan pengembangan masyarakat, norma

\footnotetext{
${ }^{10}$ Cohen and Et Al, "Participation's Place in Rural Development: Seeking Clarity through Specificity," World Development, 2018, 213-33.

11 Kakumba, "Local Government Citizen Participation and Rural Development: Reflections on Uganda's Decentralization System," International Review of Administrative Sciences, 2010, 171-86.
} 
yaitu tentang apa dapat diterima dalam hal martabat dan hak yaitu keduanya mengakui berbagai hak asasi manusia, tetapi juga menerima dan melegalkan hak tradisional atau adat. Jadi inklusi sendiri merupakan suatu keadaan dimana semua orang mampu dengan mudah mengakses apa yang menjadi hak bersama dengan memperhatikan segenap kemanfaatnya. Sehingga diharuskan semua orang mampu respek dan membantu keberlangsungan hak bagi orang lain. Inklusi bisa mencakup semua bidang baik pendidikan maupun dalam lingkungan sosial, ekonomi, politik atau segala sesuatu yang berkaitan dengan hak sebagai manusia ${ }^{12}$.

Seperti yang dijelaskan dalam pendahuluan, bahwa salah satu tujuan Negara adalah menciptakan kemakmuran bagi semua masyarakat umum maka tidak adanya pengecualian bagi segenap masyarakat untuk memperoleh kemakmuran itu sendiri. Kemakmuran tersebut harus bisa dikontribusikan dalam semua penjuru negeri baik perkotaan, pedesaan, bahkan wilayah yang belum terjamah oleh modernitas sekalipun untuk itu diperlukan pembanguan desa inklusif.

Pembangunan desa inklusif sebagai proses peningkatan kualitas hidup dan kesejahteraan ekonomi masyarakat yang tinggal di daerah pedesaan, daerah yang relative terisolir, marjinal maupun dengan penduduk yang minim ${ }^{13}$. Pembangunan pedesaan secara tradisional berpusat pada eksploitasi sumber daya alam dengan padat lahan seperti pertanian maupun kehutanan. Namun berbagai regulasi dalam mensejahteraan masyarakat telah mengubah dan memberikan warna baru serta merubah karakter pedesaan. Misalnya dengan produsen khusus, pariwisata maupun rekreasi yang telah menggantikan ekstraksi sumber daya pedesaan sebagai pendorong ekonomi yang cukup dominan ${ }^{14}$.

Kebutuhan masyarakat pedesaan untuk mendekati pembangunan yang lebih luas telah merubah paradigma lebih banyak fokus pada berbagai tujuan pembangunan dari pada hanya menciptakan insentif untuk

12 Pocock and Et al, "Integrating Data Science, Construction and Sustainability," Procedia Engineering. ICSDEC, 2016, 288-95.

${ }_{13}$ Moseley and Malcolm J, Rural Development: Principles and Practice (London: SAGE Publications, 2003).

14 Ward and Et al, "No Title," Regional Studies, 2019, 1237-44. 
pertanian atau bisinis berbasis sumber daya. Pendidikan, kewirausahaan, infrastuktur sosial semuanya memainkan peran penting dalam pengembangan daerah pedesaan ${ }^{15}$. Pembangunan pedesaan juga dicirikan pada strategi pembangunan ekonomi yang diproduksi secara lokal. Berbeda dengan Kawasan perkotaan yang lebih homogen, Kawasan pedesaan sangat berbeda satu sama lainnya. Secara umum pembangunan pedesaan lebih komprehensif, berfokus pada kegiatan untuk pengembangan wilayah di luar ekonomi perkotaan sebagai arus utama.

Kabupaten Kulonprogo merupakan salah satu daerah unik yang sedang diperbincangkan. Keunikan kabupaten ini mengenai desa inklusi, dari 8 desa rintisan 6 diantaranya terdapat di Kecamatan Lendah dan perkembagan yang sangat baik terdapat di Sidorejo dan Bumirejo. Sidorejo tersendiri merupakan salah satu desa yang terdapat di Kecamatan Lendah yang pada awalnya hanya tercatat 85 orang jumlah penyandang difabel. Akan tetapi, setelah dilakukan pendataan yang cukup menyeluruh, ternyata terdapat 360 orang jumlah penyandang difabel. Sedangkan di Bumirejo terdapat 178 penyandang disabilitas yang memang sudah di data secara rinci berdasarkan data yang diperoleh dari Sasana Integrasi dan Advokasi Difabel (SIGAB) Yogyakarta ${ }^{16}$.

Kelurahan sidareja yang dikenal sebagai desa inklusif mendapatkan perhatian penuh dari pemerintah hal ini dibuktikan dengan berbagai kegiatan yang mengakomodir serta pemenuhan kebutuhan masyarakat. Selain itu hal yang terpenting adalah adanya partisipasi aktif masyarakat dalam penentuan kehidupan mereka biasanya dilakukan saat rembuk desa. Banyaknya penyandang difabel tidak membuat redup semangat masyarakat dalam berpartisipasi bahkan sebaliknya masyrakat antusias dalam menyuarakan keinginan dan kepentingan mereka. Hal ini menjadikan desa sidareja ini dikenal sebagai desa inklusif yang aktif di kebupaten Kulonprogo ${ }^{17}$.

\footnotetext{
${ }^{15}$ Rowley, Rural Development Research: A Foundation for Policy (Westport: Greenwood Press, n.d.).

${ }^{16}$ Dokumentasi data Kelurahan, 25 Agustus 2020

17 Wawancara dengan Fikri Zulfikar, Warga desa Sidarejo Kulonprogo, 27 Agustus 2020
} 


\section{Pelaksanaan Monitoring dan Evaluasi}

Pembentukan desa inklusi merupakan salah satu usaha untuk mencapai kemakmuran bagi semua masyarakat tanpa adanya diskriminasi dan pengecualian pada masyarakat. pembentukan Desa Inklusi ini berdasarkan pada Bab I Pasal 3 Pengaturan Desa yang memiliki yang berfokus pada rekognisis, subsiadiritas, keberagaman, kebersamaan, kegotongroyonganan, kekeluargaan, musyawarah, demokrasi, kemandirian, partisipasi, kesetaraan, pemberdayaan dan keberlanjutan.

Selain itu, menelisik lebih jauh terkait Pasal 4 tentang Peraturan Desa yang memiliki tujuan sebagai berikut:

1. Memberikan pengakuan dan penghormatan atas Desa yang sudah ada dengan keberagamannya sebelum dan sesudah terbentuknya Negara Kesatuan Republik Indonesia

2. Memberikan kejelasan status dan kepastian hukum atas desa dalam sistem ketatanegaraan Republik Indonesia demi mewujudkan keadilan bagi seluruh rakyat Indonesia

3. Melestarikan dan memajukan adat, tradisi, dan budaya masyarakat desa

4. Mendorong prakarsa, gerakan, dan partisipasi masyarakat desa untuk pengembangan potensi dan aset desa guna kesejahteraan bersama

5. Membentuk pemerintahan desa yang profesional, efisien dan efektif, terbuka, serta bertanggung jawab

6. Meningkatkan pelayanan publik bagi warga masyarakat desa guna mempercepat perwujudan kesejahteraan umum

7. Meningkatkan ketahanan sosial budaya masyarakat desa guna mewujudkan masyarakat desa yang mampu memelihara kesatuan sosial sebagai bagian dari ketahanan nasional

8. Memajukan perekonomian masyarakat desa serta mengatasi kesenjangan pembangunan nasional; dan

9. Memperkuat masyarakat desa sebagai subjek pembanguna ${ }^{18}$.

18 Antok Suryaden, Integrasi Difabilitas Di Implementasi UU Desa Dan PP 43 Dan 60 Tahun 2014 (Waingapu, 2014). 
Berdasarkan penguatan perundang-undangan di atas sebagai dasar dalam pembentukan desa inklusi sudah seharusnya segenap masyarakat mendukung keseuksesan dan keberlangsungan pembangunan desa inklusi. Selanjutnya upaya dalam menjaga keberhasilan dan keberlangsungan desa inklusi tersebut harus harus adanya pengawasan dan pemantauan dalam bentuk monitoring dan evaluasi. Dalam melaksanakan monitoring dan evaluasi tentunya kita membutuhkan instrumen yang diharapkan dapat membantu semua pihak guna memperoleh informasi terkait dampak manfaat yang dihasilkan dari adanya Desa Inklusi dalam meningkatkan kesejateraan masyarakat.

Hal pertama yang akan dilakukan dalam memonitoring dan mengevaluasi Sidarejo Kabupaten Kulonprogo adalah dengan memperhatikan prinsip-prinsip yang menjadi dasar monitoring dan evaluasi yaitu berdasarkan pada standar yang diketahui bersama, terbuka, adil, berorientasi solusi, partisipatif dan berjenjang ${ }^{19}$.

Dalam hal ini monitoring dan evaluasi sebagai tindakan yang relative stabil dirancang oleh pemerintah yang dipahami oleh masyarakat desa Sidarejo. Sehingga beberapa actor bersama memecahkan suatu masalah yang menjadi perhatian bersama warga desa. Secara umum monitoring dan evaluasi akan berdampak pada hasil dan perbaikan. Evaluasi sebagai proses pemberdayaan masyarakat yang memiliki ruang lebih dalam membangun kapasitas.

Pembangunan Desa inklusi akan memberikan kesempatan bagi masyarakat yang memiliki peluang mendapatkan kesejahteraan lebih besar. Adapun yang akan penulis teliti dalam meninjau monitoring dan evaluasi pada Desa Inklusi di Kelurahan Sidorejo, Kulonprogo ada beberapa yaitu;

19 Wawancara dengan Furqon Mahmud, Warga desa Sidarejo Kulonprogo, 27 Agustus 2020 
Tabel 1. Tinjauan monitoring dan evaluasi desa inklusi di Kelurahan Sidorejo, Kulonprogo

\begin{tabular}{|c|c|c|c|}
\hline No. & Indikator & Tahap & Keterangan \\
\hline 1 & Data dan informasi & Monitoring & $\begin{array}{c}\text { Program inovasi inklusif, } \\
\text { wadah atau organisasi } \\
\text { berkumpul dalam } \\
\text { masyarakat }\end{array}$ \\
\hline 2 & Partisipasi & Monitoring & $\begin{array}{l}\text { Pendidikan, pekerjaan, } \\
\text { religiusitas serta peran, } \\
\text { proses sosial dan proses } \\
\text { politik }\end{array}$ \\
\hline 3 & $\begin{array}{l}\text { Kesetaraan akses } \\
\text { layanan umum }\end{array}$ & Evaluasi & $\begin{array}{c}\text { Adanya kesetaraan dalam } \\
\text { semua level }\end{array}$ \\
\hline 4 & $\begin{array}{l}\text { Regulasi yang } \\
\text { mendukung }\end{array}$ & Evaluasi & $\begin{array}{c}\text { Peraturan yang adil dan } \\
\text { transparan }\end{array}$ \\
\hline 5 & $\begin{array}{c}\text { Perencanaan } \\
\text { anggaran yang } \\
\text { mengarusutamakan } \\
\text { inklusi }\end{array}$ & Evaluasi & $\begin{array}{c}\text { Anggaran yang bersifat } \\
\text { inklusi }\end{array}$ \\
\hline 6 & $\begin{array}{c}\text { Problem sosial } \\
\text { dalam masyarakat }\end{array}$ & Evaluasi & $\begin{array}{l}\text { Penyimpangan dan } \\
\text { kemiskinan }\end{array}$ \\
\hline
\end{tabular}

Monitoring tahap pertama mengkorelasikan antara data dan informasi yang penulis dapatkan dari hasil observasi di lapangan. Yang diamati oleh penulis yaitu adanya program inovasi inklusif serta wadah atau organisasi berkumpul dalam masyarakat. Beberapa data yang didapatkan seperti tingkat kesejahteraan akan penulis crosscek Kembali melalui wawancara. Salah satu informan menyampaikan pernyataan bahwa, hadirnya desa inklusi memberikan dampak yang signifikan terutama dalam ekonomi keluarga ${ }^{20}$.

${ }^{20}$ Wawancara dengan Fikri Zulfikar, Warga desa Sidarejo Kulonprogo, 27 Agustus 2020 
Monitoring tahap pertisipasi, data yang penulis dapatkan dari hasil wawancara menunjukan bahwa partisipasi masyarakat relative meningkat. Peningkatan partisipasi ini searah dengan progres kesejahteraan masyarakat. Dalam pelaksanan pembangunan, masyarakat harus memiliki motivasi yang tinggi untuk berpartisipasi hal ini berkaitan dengan keberlangsungan program tersebut. Monitoring yang didapatkan dari hasil observasi desa inklusi ini menunjukan tingkat partisipasi yang tinggi. Artinya, tidak hanya ikut serta dalam pelaksanan namun anggota masyarakat juga ikut serta dalam proses perencanaan. Salah satu indikator keberhasilan partisipasi adanya inisiatif dan kreatifitas dari anggota masyarakat yang lahir dari kesadaran masyarakat. Partisipasi ini tidak hanya dalam proses sosial namun juga pada proses politik ${ }^{21}$.

Tahap evaluasi kesetaraan akses layanan umum, salah satu indikator keadilan adalah adanya kesetaraan akses layanan umum. Salah satu indikator kesetaraan dalam layanan umum adalah dengan dengan meningkatnya kesadaran dalam menjaga Kesehatan. Selain itu desa inklusi kelurahan sidorejo memiliki kesetaraan dalam layanan umum seperti saat proses politik. Masyarakat ikut serta dan tidak ada diskriminasi di dalam proses politik. Namun harus ada peningkatan pada peningkatan Pendidikan warga kelurahan sidorejo hal ini dikarena jumlah lulusan SMA maupun $\mathrm{S} 1$ yang masih minim ${ }^{22}$.

Tahap evaluasi regulasi yang mendukung, meskipun regulasi telah mendukung namun masyarakat perlu didampingi oleh praktisi dari masyarakat. Hal ini bertujuan agar warga memiliki nalar kritis yang lebih baik. Berbagai kebijakan publik telah mengarah kepada masyarakat namun dari hasil evalusi perlu pendampingan dan pemahaman berupa sosialisasi kepada masyrakat atas semua kebijakan maupun regulasi yang akan diterapkan kepada masyarakat inklusi di kelurahan Sidorejo Perlu penguatan pembentukan peraturan perundang undangan yang harus mampu mengontol kehidupan masyarakat. Selain itu juga diperlukan

21 Wawancara dengan Furqon Mahmud, Warga desa Sidarejo Kulonprogo, 27 Agustus 2020

${ }^{22}$ Wawancara dengan Fikri Zulfikar, Warga desa Sidarejo Kulonprogo, 27 Agustus 2020 
database yang terintegrasi agar memiliki informasi yang akurat serta sinkronisasi dengan peraturan perundang-undangan ${ }^{23}$.

Evaluasi terakhir yaitu adanya problem sosial dalam masyarakat. Secara umum problem sosial pada masyarakat inklusi yaitu faktor budaya seperti ketidaksesuaian pelaksanaan nilai-nilai dan norma dalam masyarakat sehingga menimbulkan perbedaan dan miskomunikasi. Faktor biologis seperti ketidakmampuan dalam menyesuaikan kondisi lingkungan dengan kurangnya fasilitas Pendidikan dan berhubungan dengan pola pikir masyarakat dalam tatanan kehidupa masyarakat. Problem yang cukup serius yaitu dengan adanya kemiskinan yang belum terselesaikan. Namun meskipun demikian upaya untuk mensejahterakan dengan berbagai inovasi program tetap dilakukan oleh pemerintah. Hal ini bertujuan untuk mengurangi angka kemiskinan ${ }^{24}$.

\section{SIMPULAN}

Monitoring dan evaluasi adalah dua kegiatan yang harus ada dalam pelaksanaan program baik dari pemerintah maupun swasta. Pentingnya monitoring dan evaluasi adalah agar program yang dijalankan sesuai dengan tujuan awal. Adanya monitoring dan evaluasi juga sebagai pengawas dan pemantau dari program. Pembangunan desa inklusi akan memberikan kesempatan bagi masyarakat yang memiliki peluang mendapatkan kesejahteraan lebih besar. Adapun yang akan penulis teliti dalam meninjau monitoring dan evaluasi pada desa inklusi di Kelurahan Sidorejo, Kulonprogo ada beberapa yaitu monitoring berupa data dan informasi dan partisipasi sementara evaluasi meliputi kesetaraan akses layanan umum, regulasi yang mendukung, perencanaan anggaran yang inklusi, problem sosial dalam masyarakat.

\footnotetext{
23 Wawancara dengan Furqon Mahmud, Warga desa Sidarejo Kulonprogo, 27 Agustus 2020

${ }^{24}$ Wawancara dengan Fikri Zulfikar, Warga desa Sidarejo Kulonprogo, 27 Agustus 2020
} 


\section{DAFTAR PUSTAKA}

Chrisna. "Action for Sustainability: Preparing an African Plan for Sustainable Building and Construction'." Building Research $\mathcal{E}$ Information, 2015, 435-44.

Cohen, and Et Al. "Participation's Place in Rural Development: Seeking Clarity through Specificity." World Development, 2018, 213-33.

Heywood, Andrew. Political Theory. Hampspire: Palgrave Macmillan, 2004.

Kadek Dwita Apriyani. “Respon Publik Terhadap Model Penganggaran Partisipatif Dalam Pembangunan Desa: Studi Tiga Provinsi Di Indonesia." Jurnal Penelitian Politik 13, no. 2 (2016): 137-48.

Kakumba. "Local Government Citizen Participation and Rural Development: Reflections on Uganda's Decentralization System." International Review of Administrative Sciences, 2010, 171-86.

Maulana, Yusuf. “Membangun Kemandirian Desa Dalam Bingkai Otonomi Daerah." Jurnal Penelitian Politik 13, no. 2 (2016): 261-68.

Moseley, and Malcolm J. Rural Development: Principles and Practice. London: SAGE Publications, 2003.

Pocock, and Et al. "Integrating Data Science, Construction and Sustainability." Procedia Engineering. ICSDEC, 2016, 288-95.

Rios, De los. "The Initiative Leader as a Model for Rural Development: Implementation to Some Territories of Mexico." Agrociencia, 2011, 60924.

Rowley. Rural Development Research: A Foundation for Policy. Westport: Greenwood Press, n.d.

Steffanie. "The Convergence of Alternative Food Networks within 'Rural Development' Initiatives: The Case of the New Rural Reconstruction Movement in China." Local Environment, 2016, 1082-99.

Suaib, Eka, and Et Al. "Desentralisasi Dan Oligarkhi Predator Di Wakatobi: Peran Oligarkhi Dan Elit Penentu Dalam Pembangunan Perdesaan." Jurnal Penelitian Politik 13, no. 2 (2016): 193-211.

Suharto, Edi. Membangun Masyarakat Memberdayakan Rakyat: Kajian Strategis Pembangunan Kesejahteraan Social Dan Pekerjaan Social. Bandung: PT. Refika Aditama, 2009. 
Suryaden, Antok. Integrasi Difabilitas Di Implementasi UU Desa Dan PP 43 Dan 60 Tahun 2014. Waingapu, 2014.

Ward, and Et al. "No Title." Regional Studies, 2019, 1237-44.

Woolcock, Michael. Social Inclusion: Its Significance for Development Theory, Research and Policy. Paris: Harvard University, 2013.

Wawancara dengan Fikri Zulfikar, Warga desa Sidarejo Kulonprogo, 27 Agustus 2020.

Wawancara dengan Furqon Mahmud, Warga desa Sidarejo Kulonprogo, 27 Agustus 2020. 